\title{
Sexual education for adolescents: parent role in rural area
}

\author{
Ema Waliyanti ${ }^{\mathrm{a}, 1, *}$, Ratna Ajeng Dewantari ${ }^{\mathrm{b}, 2}$ \\ a,b Program Studi Ilmu Keperawatan, Fakultas Kedokteran dan Ilmu Kesehatan Universitas Muhammadiyah Yogyakarta, Indonesia \\ ${ }^{1}$ emawaliyanti@umy.ac.id*; ${ }^{2}$ Senjadiorama33@gmail.com
}

ARTICLE INFO

Article history

Received, 2-nd June 2021

Revised, $11^{\text {st }}$ August 2021

Accepted, $16^{\text {th }}$ October 2021

Keywords

Adolescent

Parent

Sexual education

\section{ABSTRACT}

Health problems faced by adolescents when they are very varied and related to risky sexual behavior. Sexual education is currently still considered taboo by the public because it is less appropriate to talk about and is private. The purpose of this study was to explore the role of parents in sexual education in adolescents. This study uses a qualitative research method with a phenomenological approach. Data were collected by means of in-depth interviews with 12 participants who were determined by purposive sampling. The saturation data with 5 parent and 7 adolescents. Data validity test used source triangulation, member cheking, peer debrifing, and thick description. Data analysis using open code 4.03 software. This research is ethical with number No. 020 / EC-KEPK FKIK UMY / I / 2021. The results showed that the role of parents in providing sex education to adolescents was caused by several factors, namely the closeness of children to their parents, parental education, parental divorce, parents' perceptions of sex education, perceptions of the importance of sex education, and parenting styles of parents to child, which affect the optimal role of parents in sex education for their children. To conclude, it is important for parents to provide sexual education to prevent risky sexual behavior, such as providing sexual education for adolescents, giving advice to children, supervising children's relationships, and providing rules for children.

This is an open access article under the CC-BY-SA license.

\section{Introduction}

The National Population Planning Board (BKKBN, 2017) explained that the health problems faced by adolescents are various and related to risky behavior, for example premarital sexual behavior, unwanted pregnancy, sexually transmitted diseases such as HIV/AIDS, drug abuse (narcotics, psychotropic substances, substances) other addictive (BKKBN, 2017). The results of a survey from the Indonesian Adolescent Reproductive Health (SKKRI) in 2015 showed 79.6\% male and 71.6\% female adolescents had held hands, $29.5 \%$ male and $6.2 \%$ teenage girls felt their partners, $48.1 \%$ boys and $29.3 \%$ girls had kissed. Another case was an increase in the number of HIV/AIDS cases in Medan by 568 incidents with the number of school children/students as many as 84 cases. According to the 2017 Indonesian Health Data Survey data, 12\% of women said they had experienced an unwanted pregnancy and $7 \%$ of men reported that their partner had an unwanted pregnancy. According to the Yogyakarta health office, in 2015 there were a total of 1078 cases of childbirth in adolescents consisting of: Gunungkidul 405 cases, Bantul 364 cases, Sleman 110 cases, Kulonprogo 107 cases, and Yogyakarta City 92 case.

The high risk sexual behavior carried out by adolescents is caused by several factors, namely internal factors and external factors. According to (Umaroh et al., 2016) internal factors that can cause risky sexual behavior are the level of education, knowledge, attitudes, and lifestyles and external 
factors that influence is the role of the closest person who is usually invited to discuss sex, where to live whether in an urban or rural area., and media sources of information.

Efforts that can be made to prevent this problem are providing information, especially regarding sexuality. Adolescents have active sexual potential due to the influence of hormones that encourage adolescents to engage in risky behavior, while the information which obtained is inadequate (Anggraeni, 2017). According to (Sofyan \& Sauri, 2017), sexual education is very important, especially for teenagers because it will have an impact on the survival of teenagers' lives. When parents think that sexual education is a taboo subject, adolescents' knowledge about sexuality will decrease. Teenagers who do not understand will do things such as accessing media that presents pornographic news, such as VCDs, magazines, the internet, and even television shows that have led to matters related to sexuality.

Teenagers' lack of understanding regarding sexual education will make them do negative things such as having sex outside of marriage, abortion or aborting a pregnancy, contracting sexually transmitted diseases such as syphilis, gonorrhea, herpes, chlamydia and even HIV/AIDS (Kasim, 2017). In addition, other negative things caused are feelings of guilt, fear, anxiety, stress, shame in the event of pregnancy and being ostracized by society, depression to suicide (Lestari \& Awaru, n.d.). Therefore, sexual education provided by parents to adolescents is very important so that adolescents avoid unwanted negative impacts.

Currently, sexual education that should be carried out by parents is still a taboo subject to be discussed further. Most parents in Indonesia still feel clumsy while talking about reproductive health and sexuality issues to their children who are starting to grow into adolescents. Meanwhile, teenagers tend to feel embarrassed to ask questions and tell about what happened about their sexual dynamics to their parents (Lavie \& Ajayi, 2015). Another factor, namely sexual education, is still considered contrary to moral values because sexual education is still something that is rarely discussed or foreign to be further understood in the general public (Santelli et al., 2018). Most of people consider sexual education as pornography, but it all depends on the time, place, and circumstances of each region as well as differences in background (Haryani, 2015). The role of parents with adolescents is an important aspect of this because the family is the main source of personality formation and the delivery of health messages, including adolescent reproductive health (Pattiruhu et al., 2019). According to (Purwatiningsih, 2019), the level of communication between parents and adolescents in discussing reproductive health issues is low, even though parent-adolescent communication has an important role. Education when it is at the formal level is the provision of guidance that is directed to someone who is and leads to the provision of knowledge and character building in terms of physical and spiritual. Parents are the most important teachers because they are the ones who accompany their teenage daughters from childhood to adulthood so that education in the family environment is an important factor in children's growth and development The purpose of this study was to explore the role of parents in sexual education in adolescents

\section{Methods}

This research design adapted a qualitative method with a phenomenological approach. The number of participants in this study were 12 people in Petung Hamlet and Kalipucang Hamlet, Bangunjiwo Village, Kasihan District, Bantul Regency. The sampling used was purposive sampling. The inclusion criteria in this study are:

Table 1. Participants criteria

\begin{tabular}{cc} 
Adolescents & Parents \\
\hline Willing to be a respondent in data collection & Willing to be a respondent in data collection \\
\hline Able to communicate verbally well & Able to communicate verbally well \\
\hline $\begin{array}{c}\text { Residing in Petung and Kalipucang hamlets, Bantul } \\
\text { Regency }\end{array}$ & $\begin{array}{c}\text { Residing in Petung and Kalipucang hamlets, Bantul } \\
\text { Regency }\end{array}$ \\
\hline $\begin{array}{c}\text { Adolescents who have a history of risky behavior aged } \\
12-22 \text { years }\end{array}$ & $\begin{array}{c}\text { Parents who have children with a history of risky behavior } \\
\text { aged 12-22 years }\end{array}$ \\
\hline
\end{tabular}

After obtaining an ethical license with the number 020 / EC-KEPK FKIK UMY / I / 2021 and the statement of ethics worthy of "ETHICAL APPROVAL" is declared worthy of ethics according to 7 
(seven) WHO 2011 standards, namely social values, scientific values, distribution of burdens and benefits, risk, persuasion / exploitation, confidentiality and privacy, and consent after the explanation referring to the 2016 CIOMS guidelines this research was conducted in December 2020-February 2021.

Data were collected using in-depth interviews. The instrument used in this study was an in-depth interview guide containing open-ended questions regarding the role of parents in providing sexual education to adolescents such as what information on reproductive health are provided by parents to children and the experience of parents in supervising children's growth and development, including reproductive health. In addition, questions related to factors that influence parents in providing reproductive health education to adolescents, field notes, and recorders. voice recorder. Analysis of the data in this study was applied by analyzing and classifying the meaning data from the statement of the research results by drawing conclusions in the form of big themes. Data analysis using open code 4.03 software. Data validity test used triangulation, member check, peer debrifing, thick description (solid description).

\section{Results}

Participants in this study were 12 people consisting of 7 adolescents and 5 parents with the following participant characteristics:

Table 2. Participants characteristics

\begin{tabular}{cccccc}
\hline Partisipan Code & Gender & Age & Recent Education & Occupation & Status \\
\hline Participant 1 & Female & $22^{\text {nd }}$ & Senior High School & Student & Adolescent \\
\hline Participant 2 & Female & $17^{\text {th }}$ & Senior High School & Student & Adolescent \\
\hline Participant 3 & Female & $16^{\text {th }}$ & Vocational High School & Student & Adolescent \\
\hline Participant 4 & Male & $21^{\text {st }}$ & Senior High School & Student & Adolescent \\
\hline Participant 5 & Male & $21^{\text {st }}$ & Senior High School & Student & Adolescent \\
\hline Participant 6 & Male & $20^{\text {th }}$ & Vocational High School & Private Employees & Adolescent \\
\hline Participant 7 & Male & $16^{\text {th }}$ & Vocational High School & Student & Adolescent \\
\hline Participant 8 & Female & $46^{\text {th }}$ & Junior High School & Laborer & Parent \\
\hline Participant 9 & Female & $46^{\text {th }}$ & Senior High School & Housewife & Parent \\
\hline Participant 10 & Female & $41^{\text {st }}$ & Junior High School & Laborer & Parent \\
\hline Participant 11 & Female & $48^{\text {th }}$ & Elementary School & Laborer & Parent \\
\hline Participant 12 & Female & $35^{\text {th }}$ & Senior High School & Housewife & Parent
\end{tabular}

The results showed that the role of parents in providing sex education to adolescents was caused by several factors, namely the closeness of children to their parents, parental education, parental divorce, parents' perceptions of sex education, perceptions of the importance of sex education, and parenting styles to child. These factors affect the role of parents in sex education for adolescents, including teaching sex education to children, giving advice to children, carrying out parental supervision of children, and providing parental rules to children. 


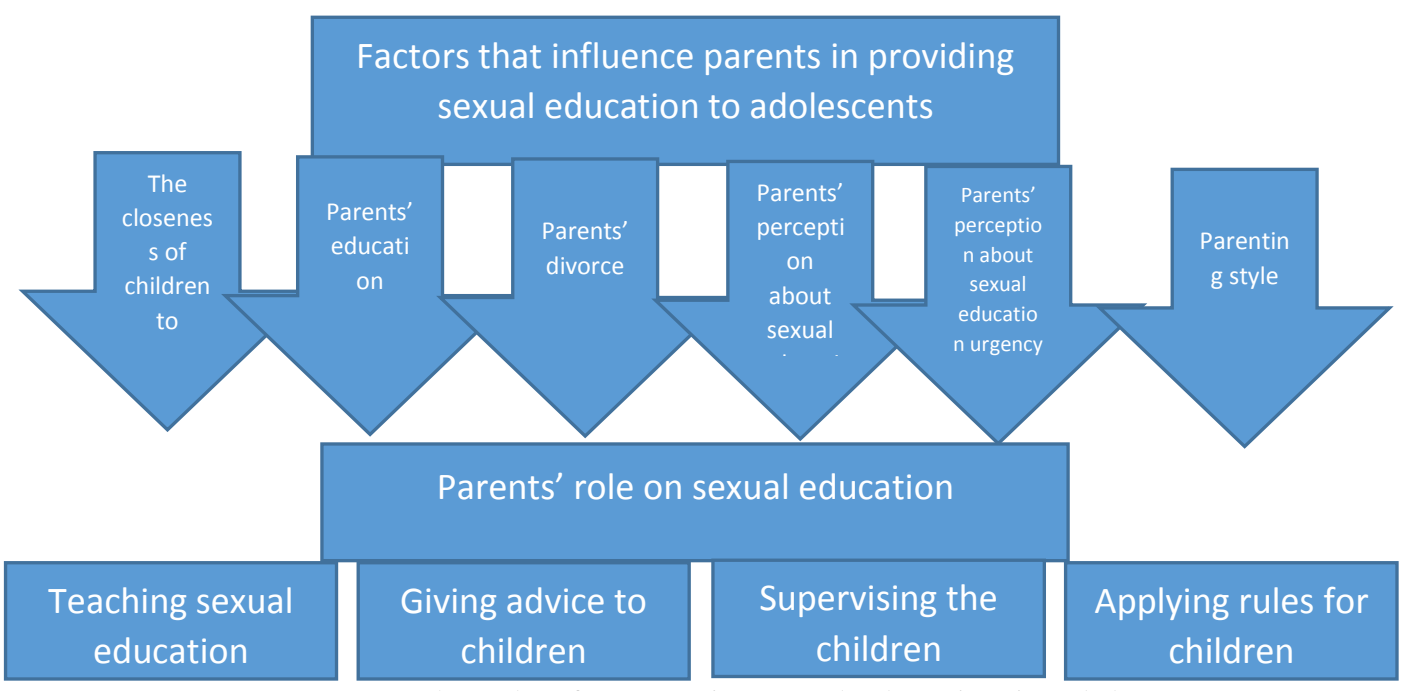

Fig. 1. The role of parents in sexual education in adolescents

\subsection{Factors that influence parents in providing sexual education}

The results showed that the closeness of children to their parents was one of the factors in providing sexual education to children. The closeness of children to parents makes children feel that parents are a place to tell stories, even as friends to confide in, usually children feel less or not close to their parents because their parents are busy working. One participant stated that:

"About my closeness, it's not really close, Miss., if I come home from work she has gone to play or sleep, I work at home too. It's very rare to see my child. "(Parent, female, 46 years old)

The second factor was parental education. The results of the interviews showed that the factors which influence parents in providing sexual education to children was parents only graduate from elementary and junior high school. This was related to the knowledge possessed by parents and affects the conversation between children and parents. Teenagers said that they had limitations in conversations with parents because sometimes parents did not know and did not understand what is happening at this time. On the other hand, parents also said that they felt they were lacking in knowledge because they only graduated from elementary and junior high school. One participant stated that:

"Eee because of what? Maybe because they were all elementary school graduates. Automatically, they probably only know that there are limits, you know, so it actually affects, for example, me as mother, I also have the same high graduates with my daughter, so automatically if she have a problem we can chat each other, but because I only graduated from elementary school, maybe there are some cases or problems. or what I can't talk about when I talk about it, there must be a limit, you know "(Teenager, Female, 22 years old)

The third factor was parental divorce. The results of the interviews conducted show that parental divorce was one of the factors for parents in providing sexual education to their children. The divorce factor of the parents made the child less attentive, adolescents say that they did not know the condition of one of their parents because they had been separated for a long time. One participant stated that:

"My father and my mother divorced since I was 2 years old, I don't know where was my father but I think he had already a wife and had another child, my father was a Jogja citizen, Miss" (Teenager, female, 16 years)

The fourth factor was parents' perceptions of sexual education. The results of the interviews conducted showed that parents considered sexual education a taboo subject. Some parents said they did not know how to convey to their children and thought sex education was inappropriate because of privacy. Parents assumed that when teenagers were asked about their sexuality they would be embarrassed and think that they can tell by themselves. Conversely, adolescents assume that their parents did not provide sexual education to them because for them sexual education was unusual - it was different from subject such as mathematics or language. One participant stated that: 
"Yes, now, that person wants to talk like a very careful person, you know, if you talk too much about it, the impression looks like how come you really know. Still like that, maybe what are you still doing, you still can't accept it when we talk about it, it's like limiting it. Maybe they think that such talk is not suitable to be discussed in daily life" (Teenager, Female, 17 years old)

The fifth factor was the perception of the importance of sexual education. The results of the interviews conducted show that this perception was related to several impacts that may occured when sexual education was not provided to adolescents, for example, juvenile delinquency would be occured, adolescents would engage in risky behavior, causing adolescents to experience pregnancy outside of marriage, sexually transmitted diseases, the front would be destroyed. In addition, adolescents also said that when they were pregnant outside of marriage they would experience early maturity due to circumstances, and would experience losses to themselves. One participant stated that:

"Yes, for sure, like in this area, Miss, there is no education about sexuality, the impact of getting pregnant outside of marriage, and when pregnant outside of marriage. Most of them follow their parents" (teenager, male, 21 years old)

The sixth factor is the parenting style that parents apply to their children. The results of the interviews showed that the factor that influenced parents to provide sexual education was their parenting style for their children. Parents said that they let their children explore their life. However, they also tried to monitor their children's interactions and when their children did things that are not reasonable, they will advise them. Moreover, they always remind them that whatever they had done there must be risks. One participant stated that:

"Yeah, it's free but there is responsibility, it's limited, you can't go, but it's clear to whom, at what time" (Parent, female, 35 years).

\subsection{The role of parents in sexual education}

The first role of parents in sexual education is to teach sexual education to children. The results of the interview showed that parents gave some sexual education to their children, such as explanation about which parts of the body that allowed to be held by other people, teaching about putting on sanitary napkins during their first menstruation, telling to clean their genitals, and explanation to male adolescents that their first circumcision marked their body growth. One participant stated that:

"This part of the chest cannot be held, my child is a girl, miss, it means that there are many parts of the body that can not be held by other people, and the persons who could hold this are only you and your mother. If the others hold it, tell me." (Parents, Female, 35 years old)

The second role of parents in sexual education was parental advice. The results of the interview showed that the advice given by parents to children was related to the child's association. There are many parental advice statement example, such as a command to hanging out with good person, a command to to take care of theirself, and a command to be careful when dating with someone to avoid inappropriate things. One of the participants stated that:

"Yes, I will tell her that she is allowed to date, but I warn her to take an appropriate relationship, be careful and don't do something weird. She must take care of her body" (Parent, Female, 41 years old)

The third role of parents in sexual education was parental supervision of children. The results of the interview showed that parents supervised children's interactions in several ways, including contacting children by telephone or via message periodically, asking about the child's position when they are away, and asking their children to send their current location photo as evidence, and approaching their child at the their playground if they had not gave any answer. One participant stated that:

"Until her adulthood, she is still my daughter. For example at 9 p.m. or 10 p.m., if she hasn't come home yet, I'll send a WA (WhatsApp) message to her," (Parent, Female, 46 years old)

The fourth role of parents in sexual education was the applied the rules to children. The results of the interview showed that the parental rules that were applied to children include limitation on playing time, unallowing to stay at friends' houses, restricting them to have a date, or unallowing children to date. One of the participants stated that: 
"If she is going out last night, we don't allow her to go out at night, miss. At least, at night, the limit is 9pm, she has to be at home. Then if she plays outside, she is allowed to have a clear explanation. Where do you play with? (Parent, Female, 35 years old)

\section{Discussion}

\subsection{The closeness of children to parents}

The results showed that the closeness of children to their parents is one of the factors in providing sexual education to children. Based on our evidence, the closeness of children to parents made children feel that parents were a place to tell stories, even as friends to confide in. Otherwise, children feel less or not close to their parents because their parents excessive business.

This is in accordance with research from (Lusiana, 2019) which states that working parents often do not provide sexual education to their children because parents have limited time to meet their children and make children feel alien to their parents. Adolescence is a time when there are several changes, including physical and psychological changes. Therefore the role of parents is very important in accompanying adolescents in their growth process (Devi et al., 2019).

\subsection{Parental education}

Parental education is another factor in providing sexual education to children. Based on our research results, parents with a low level of education had an effect on the quality of conversations between children and parents. Regarding this, parental education was also related to parental knowledge of sexual education. This is in accordance with research from Rahmawati which states that parents with higher education will more closely follow the development of their children and tend to have broad and diplomatic thinking and are advanced compared to parents with low education (Rahmawati et al., 2019).

Moreover, (Sulastri \& Tarmiz, 2017) states that parents with higher education find it easier to access information about sexual education for their children from both electronic and print media [9]. This kind of education media has become a major contribution in increasing children's knowledge related to sexual education (Bloomberg et al., 2021).

\subsection{Parental divorce}

Parental divorce is a factor in providing sexual education because parents with divorce status affected the form of the family. The form of an incomplete family would overwhelm the parent or single parent in caring their children. Single parents would educate their children by themselves without assistance from a partner which lead to inoptimal education.

This is supported by previous researches which state that a person with a single mom/single dad status will play two roles at once, namely taking care of the family and providing for the family. A single parent, furthermore will not easy to do various things at once, especially in providing sexual education (Wirdanengsih, 2021).

\subsection{Parents' perceptions of sexual education}

Parents' perceptions of sexual education are the factor in providing sexual education for their children. This perception is the benchmark for parents to view sexual education. Parents who still regard sexual education as taboo would have an effect on what sexual education has been given to their children. Based on our research results, parents considered sexual education taboo because sexuality was a private thing. Therefore, it was inappropriate to be discussed.

This is supported by research (Nadar., 2018) which states that parents' perceptions of sexual education consider taboo due to lack of information and society considers sexual education to be something that is not worth talking about. Society believes that sexual education is not appropriate for adolescents because it is a personal matter (Haley \& Tordoff, 2019).

(Bauer et al., 2020), furthermore explains that cultural factors are one of the elements related to parents' perceptions of sexual education, this cultural factor prohibits talking about sex in public because it is considered as pornography which is very private and cannot be disclosed in general. 
(Goldfarb \& Lieberman, 2021) explained that sexual education is taboo because usually parents only focus on formal education. Parents assume that children will know by themselves without their parents explaining because everyone will experience it (Nelson et al., 2019).

\subsection{Perceptions of the importance of sexual education}

The perception of the importance of sexual education is also a factor in providing sexual education to children. This is usually related to the likelihood or impact that could occured when sexual education is not given to children. The results showed that these arguments could led to possible impacts such as juvenile delinquency, promiscuity, free sex, the possibility of teenagers getting pregnant outside of marriage and even sexually transmitted diseases.

This is supported by research from (Ciptiasrini \& Astarie, 2002) which states that the impact of inadequate sex education can result in adolescents engagement on risky sexual behavior such as deviant sexual behavior, drug abuse, and sexual violence. Furthermore, (Gaol \& Stevanus, 2019) explains that uncontrolled knowledge of sex through parental assistance usually leads to deviations such as free sex, sex outside marriage. This is because adolescents feel curious and unable to control their own behavior.

\subsection{Parenting style}

Parents' upbringing is a factor in providing sexual education. Based on our evidence, free parenting style made children feel that they had no responsibility towards themselves and felt that what they did always right. Authoritarian parenting made children feel constrained and tend to have difficulty in socializing. On the other hand, parents who applied responsible parenting to their children made the children feel that what they did has risks and the children would be careful in their behavior.

This is supported by research (Leung \& Lin, 2019) which states that parenting is a way for parents to educate their children as a manifestation of parental responsibility to children. (Wees et al., 2021) explained that adolescents tend to engage in risky sexual behavior because adolescents feel there is no prohibition from their parents and often do not know whether what is being done is right or wrong, good or not.

(Puspita \& Telogorejo, 2019) explains that authoritarian parenting makes parents fully control the activities of the child and applies rules that limit him in socializing. In this authoritarian parenting pattern, parents do not hesitate to hit and scold when children violate them so that children feel constrained by parental rules (Chen et al., 2017). On the other hand, democratic parenting or often called free and responsible makes children feel responsible for what they do and usually parents give children the opportunity to make their own decisions and support and direct what is good and right for children (Yoost et al., 2021).

\subsection{Sexual education teaching}

Teaching sexual education is one of the roles of parents in sex education. Teaching sexual education is related to the efforts made by parents to teach adolescents related to sexuality in order to know the development and overcome the problems faced by adolescents, for example, children are taught about body parts that can be held by other people and not, parents provide information related to menstruation or wet dreams (Zulfaya, 2020).

This is supported by research from (Lindawati \& Nurdiyanti, 2020) which states that sex education emphasizes the understanding of the child's body condition that must be maintained and others should not touch carelessly sensitive or prohibited parts of the body. Moreover, (Achora et al., 2018) explains that understanding sexual education is useful for avoiding sexual violence in adolescents and it is hoped that sexual education from parents can prevent children from sexual deviations.

Teaching sexual education can be done such as telling children that they have full rights over themselves and saying that they are obliged to protect themselves from the touch of others except parents and medical personnel (Cheedalla et al., 2020). (Plastino et al., 2017) states that parents have the right to sexual education for adolescents and introduce to their children about wet dreams in boys and menstruation in women as well as the potential for pregnancy and sexually transmitted diseases.

\subsection{Parental advice}

Parents' advice is one of the roles of parents in sex education. Parents' advice is a message from parents for adolescents to understand their intentions and goals in educating. (Adawiah, 2017) explains 
that advice is usually in the form of a mandate for adolescents related to their relationships, friendships, and social life. This is supported by research (Mustika et al., 2019) which states that advice is a form of parent's concern for their children and shows that parents have expectations for their children regarding the actions they have taken. The advice given usually reminds teenagers to do good and not deviate from existing rules or norms (Rinta, 2015).

\subsection{Parental supervision}

Parental supervision is the role of parents in sexual education to find out how the child is outside the home and can find out (Yendi, 2020) what the child is doing. Based on our results, supervision was usually in the form of questions from parents to children such as the position of the child's whereabouts, who the children was with outside, and how their condition was outside the home.

This is supported by research (Saputro, 2018) which states that supervision outside the home can be in the form of messages, sending pictures, and calling children to ascertain what activities the child is doing when outside the home. Supervision is carried out so that parents do not feel worried about the condition of the child outside the home and ensure whether what the child says is true or not (Rudick, 2020). Explains the causes of risky sexual behavior in adolescents due to lack of parental supervision and attention, as well as a free environment that makes children have risky sexual behavior.

\subsection{Parental rules for children}

The last role of parents in sex education is the rules estabilishment to children. Based on our results, the rules were given in order to control some children activity. The rules, for example, were applying playing hours rules or relationships limitation with the opposite sex. This is supported by research from (Thania, 2021) which states that rules made by parents will have a good impact on children and make children think whether what is done is right or wrong.

(Utami, 2019), furthermore, explains that this rule is made so that children have good self-control and are able to avoid the impact of risky sexual behavior. The rules given to children are in fact effectively applied because they are a series of efforts made by parents in building character in children (Yanuarti, 2019).

Apart from this, we admit that this study still has weaknesses, namely that this study did not involve male parents.

\section{Conclusion}

Risk behavior in adolescents is one of the problems faced by adolescents in the transition period, usually adolescents who engaged in risky sexual behavior due to the lack of the role of parents in providing sexual education for adolescents.

The factors that influence parents in providing sexual education including the closeness of children to parents, parental education, parental divorce, parents' perceptions of sex education, perceptions of the importance of sex education, and parenting styles applied to children. The role of parents in sexual education is in the form of teaching sexual education to children, providing advice to children, and supervising children regarding relationships, and providing rules for children. Therefore it is important for parents to provide sexual education to prevent risky sexual behavior.

\section{Acknowledgment}

We thank to Universitas Muhammadiyah Yogyakarta for providing support for the implementation of this research. Thanks also to all participants, all youth cadres in Petung Hamlet and Kalipucang Hamlet who were willing and assisted in the data collection process. 


\section{References}

Achora, Thupayagale, \& Tshweneagae. (2018). Perceptions of adolescents and teachers on schoolbased sexuality education in rural primary schools in Uganda. Sexual and Reproductive Healthcare, 17(1), 12-18. https://doi.org/10.1016/j.srhc.2018.05.002

Adawiah. (2017). The Parenting and Its Implications for Children's Education: A Study on the Dayak Community in Parenting and Its Implications on Children's Education (The Study Case of the Dayak Community in Halong District, Balangan Regency). 7(1), 33-48. http://dx.doi.org/10.20527/kewarganegaraan.v7i1.3534

Anggraeni. (2017). The Factors Associated with Parents' Knowledge Level of Sexual Education in Early Childhood at Kartika Elementary School Class VIII-5 South Jakarta in 2014. 1(2), 2328. https://doi.org/10.29313/ga.v1i2.3383

Bauer, Hämmerli, \& Leeners. (2020). Unmet Needs in Sex Education-What Adolescents Aim to Understand About Sexuality of the Other Sex. Journal of Adolescent Health, 67(2), 245-252. https://doi.org/10.1016/j.jadohealth.2020.02.015

BKKBN. (2017). Regulation of the Head of the National Population and Family Planning Agency Number 24 of 2017 concerning Post-partum and Post-Miscarriage Family Planning Services. In Jakarta: $B K K B N$.

Bloomberg, Dugravot, \& Dumurgier. (2021). Sex differences and the role of education in cognitive ageing: analysis of two UK-based prospective cohort studies. Environ. Res. Public Health Nature The Lancet Public Health, 6(2), 106-115.

Cheedalla, Moreau, \& Burke. (2020). Sex education and contraceptive use of adolescent and young adult females in the United States: an analysis of the National Survey of Family Growth 20112017. 10(2). https://doi.org/10.1016/j.conx.2020.100048

Chen, Dunne, \& Han. (2017). Prevention of child sexual abuse in China: Knowledge, attitudes, and communication practices of parents of elementary school children. Child Abuse and Neglect, 31(7), 747-755. https://doi.org/10.1016/j.chiabu.2006.12.013

Ciptiasrini, \& Astarie. (2002). Parents' Perception and Role on Giving Sexual Education to Children. Jurnal Kebidanan Dan Keperawatan Aisyiyah, 16(1), 19-26.

Devi, Soekardi, \& Kurniasih. (2019). The Relationship between the Implementation of 8 Family Functions and the Attitudes of Yogyakarta High School Students Against Juvenile Delinquency (Klithih) in Yogyakarta in 2019. Medika Respati, 14(2), 132. https://doi.org/10.35842/mr.v14i2.249

Gaol, L., \& Stevanus. (2019). Sex Education in Teens. FIDEI, 2(2), 325-343, 2(2), 325-343. https://doi.org/10.34081/fidei.v2i2.76

Goldfarb, \& Lieberman. (2021). Three Decades of Research: The Case for Comprehensive Sex Education. Journal of Adolescent Health, 68(1), 13-27. https://doi.org/10.1016/j.jadohealth.2020.07.036

Haley, \& Tordoff. (2019). Sex Education for Transgender and Non-Binary Youth: Previous Experiences and Recommended Content. Journal of Sexual Medicine, 16(11), 1834-1848. https://doi.org/10.1016/j.jsxm.2019.08.009

Haryani. (2015). The Role of Parents Related to Pre-Marital Sexual Behavior of Adolescents in SMKN 1 Sedayu. Journal Ners And Midwifery Indonesia, 3(3), 140-144.

Kasim. (2017). The Impact of Risky Sexual Behavior on Reproductive Health and its Handling Efforts. Pustaka Kesehatan, 3(1). 
Lavie, \& Ajayi. (2015). Informal Sex Education by Youth Practitioners. 28(5), 485-501. https://doi.org/10.1177/1103308819899564

Lestari, \& Awaru. (n.d.). The Impact of Sexual Knowledge on Adolescent Sexual Behavior in Manggala District, Makassar City. 7(1), 21. https://doi.org/10.26858/sosialisasi.v0i0.13885

Leung, \& Lin. (2019). Adolescent Sexual Risk Behavior in Hong Kong: Prevalence, Protective Factors, and Sex Education Programs. Journal of Adolescent Health, 64(6), 52-58.

Lindawati, \& Nurdiyanti. (2020). The Implantation of Reproductive Health Education in Children since Early Age in the Family. Universitas Muhammadiyah Ponorogo Scientifc Journal, 1(1), $22-30$.

Lusiana. (2019). The Influential Factos of Sex Education in Early Adolescents Ages 10-13 Years. 2(1), 204-209.

Mustika, Maranatha, \& Justicia. (2019). Analysis of the Single Mother's Role in Education. RECEP, $1(1), 61-69$.

Nadar. (2018). Parents' Perception of Sex Education for Early Childhood. Yaa Bunayya, 1(2), 77 90.

Nelson, Pantalone, \& Carey. (2019). Sexual Health Education for Adolescent Males Who Are Interested in Sex With Males: An Investigation of Experiences, Preferences, and Needs. Journal of Adolescent Health, 64(1), 61-69. https://doi.org/10.1016/j.jadohealth.2018.07.015

Pattiruhu, Rompas, \& Simak. (2019). Family Affective Function And Family Socialization Function to The Adolescent Sexual Behavior. Jurnal Keperawatan, 7(2), 1-9.

Plastino, Quinlan, Todd, \& Tevendale. (2017). Stakeholder Education and Community Mobilization Garner Support for Sex Education. Journal of Adolescent Health, 60(3), 24-29. https://doi.org/10.1016/j.jadohealth.2016.09.028

Purwatiningsih. (2019). Adolescent Sexual Behavior and The Effect of The Social Environment among Children of Migran and Non-Migrant Households. Jurnal Universitas Gadjah Mada, 27(1), 1-16.

Puspita, \& Telogorejo. (2019). The Relationship of Parenting Patterns to Adolescent Sexual Knowledge. 5(2), 40-44.

Rahmawati, Suminar, \& Soedirham. (2019). The Personal Relationship of Adolescents with the Implementation of Character Education by Parents in Efforts to Prevent Premarital Sexual Behavior in Jember Regency. Kesehatan Reproduksi, 9(2), 149-152. https://doi.org/10.22435/kespro.v9i2.2028.149-157

Rinta. (2015). Sexual Education in Shaping Positive Sexual Behavior in Adolescents and Its Implications for Adolescent Psychological Resilience. Ketahanan Nasional, 21(3), 163. https://doi.org/10.22146/jkn.15587 https://doi.org/10.14421/aplikasia.v17i1.1362

Rudick. (2020). From sex-ed to fertility-ed: a more holistic approach to reproductive education. $F \& S$ Reports, 1(3), 166-167. https://doi.org/10.1016/j.xfre.2020.10.007

Santelli, Grilo, \& Choo. (2018). Does sex education before college protect students from sexual assault in college? PLoS ONE, 13(11), 1-19. https://doi.org/10.1371/journal.pone.0205951

Saputro. (2018). Understanding the Characteristics and Developmental Tasks of Adolescence. Aplikasia, 17(1), 25.

Sofyan, \& Sauri. (2017). Sex Education.

Sulastri, \& Tarmiz, A. (2017). The Role of Parents in Early Childhood Education. Raudhatul Athfal, 
1(1), 61-80. https://doi.org/10.19109/ra.v1i1.1526

Thania. (2021). Permissive Parenting with Sexual Behavior in Adolescents. Social Library, 1(1), 3139.

Umaroh, Kusumawati, \& Kasjono. (2016). The Relationship Between Internal Factors And External Factors With Adolescent Premarital Sexual Behavior In Indonesia. Kesehatan Masyarakat Andalas, 10(1), 66-75.

Utami. (2019). Parental Practices in Supervising Adolescent Intercourse to Prevent Unwanted Pregnancy. Care, 7(2), 7-15. https://doi.org/10.33366/jc.v7i2.1043

Wees, V., Fried, \& Larsson. (2021). Arabic speaking migrant parents' perceptions of sex education in Sweden: A qualitative study. Sexual and Reproductive Healthcare, 109605. https://doi.org/10.1016/j.srhc.2021.100596

Wirdanengsih. (2021). The Role of Mothers in the Process of Sexual Education in Children Aged 46 Years (The Study Case of Single Mom in the Village of Gurun Laweh, Padang City). Perspektif, 4(1), 146-157.

Yanuarti. (2019). Islamic Parenting Patterns for Parents in Preventing the Emergence of LGBT Behavior since Early Age. Cendekia, 17(1), 57-80. https://doi.org/10.21154/cendekia.v17i1.1337

Yendi. (2020). Prevention of adolescent sexual behavior: Can be with family counseling? JRTI, 4(1), 44-47. https://doi.org/10.29210/3003474000

Yoost, Ruley, \& Durfee. (2021). Acceptability of a Comprehensive Sex Education Self-Study Website for Teaching Reproductive Health: A Pilot Study Among College Students and Obstetrics and Gynecology Resident Physicians. Sexual Medicine, 9(1). https://doi.org/10.1016/j.esxm.2020.100302

Zulfaya. (2020). The Use of Whatsapp in Increasing Parents' Understanding of Positive Communication With Children. Community Education Journal, 3(3), 290. https://doi.org/10.22460/comm-edu.v3i3.4558 